\title{
Teatteri ja draama työn oppimismuotoina
}

\author{
$+y$ \\ Työelämän muutos edellyttää uusia näkökulmia myös \\ työn kehittämiseen. Teatteri ja draama tarjoavat menetelmän \\ osallistaa henkilökunta kehittämään organisaation \\ toimintatapoja.
}

TYÖELÄMÄSTRATEGIAN TAVOITTEENA on, että Suomen työelämä olisi Euroopan parasta vuonna 2020. Työelämä 2020 -hankkeen esitteen mukaan: "Kärkipaikalle päästäaseen Suomen pitäisi kehittyä johtamisen ja innovoinnin saralla. Tavoitteena on, että tulevaisuudessa y hä useammalla työpaikalla vallitsee uudistumista ja kehittämistä tukeva kulttuuri, jossa tuotteet, palvelut ja toimintatavat luodaan yhteistyössä. Toiminta on avointa, vuorovaikutteista, hallittua ja ennakoivaa".

Työelämän muutos on tuonut uusia näkökulmia työn kehittämiseen. Muutos näyttää olevan erityisen haasteellinen julkisen sektorin palveluorganisaatioille, joissa asiantuntijuus ja työnteon tavat ovat kytköksissä historian saatossa syntyneeseen byrokraattiseen ja hierarkkiseen malliin. Organisaatiot hakevat yhä nopeammissa sykleissä uudenlaisia joustavia työkäytänteitä, toimintamalleja ja tekemisen muotoja, jotka ylittävät perinteisen työnjaon rajat. Ammattilaisten uudenlaiset identiteetit edellyttävät neuvottelua ja henkilöstön näkemysten huomiointia. Monesti kehittämisprojekteissa joudutaan soutamaan samalla, kun venettä vasta rakennetaan.

Seuraava muutostarina havainnollistaa eri henkilöstöryhmien näkemyksiä käynnissä olevista kehittämispyrkimyksistä. Rovaniemen Teatterissa monipuolistettiin teatterin harjoitusprosesseja ja palkattiin soveltavan draaman ammattilaisia, alueteatterikuraattoreja, jotka toivat mukanaan erilaisia teatterin tekemisen tapoja, harjoitusprosesseja ja tuotantomalleja. Johdon edustaja kuvasi näkemystään työtapojen monipuolistumisesta näin: 
"Voisimme kohdata yleisön muutenkin kuin aina ennen. Olisi tärkeätä saada koko henkilökunta sitoutumaan siihen näkemykseen, että omaa ammattitaitoa, ilmaisutapoja ja uudenlaista suhdetta yleisöön tullaan kehittämään yhteistyössä muiden kanssa. Olisi tärkeää, että henkilöstö haluaa ottaa vastuuta omasta kehityksestään eikä puolustaudu ajatellen, että muutos on uhka. Muuttuminen voi olla hauskaa ja kehittyminen kivaa. Meidän pitäisi elinikäisen oppimisen tavoin kannustaa jatkuvaan uteliaisuuteen. Toivon mukaan emme sano uusiin asioihin 'toi on - - kauheeta' vaan pikemminkin 'en ihan vielä ymmärrä, pitääpä ottaa selvää."

Soveltavan draaman ammattilaisten produktioissa näyttelijät joutuivat omaksumaan lyhyellä aikavälillä uusia teatterin tekemisen periaatteita ja käytänteitä. Näin alueteatterikuraattorien käsitys teatterin perustehtävästä poikkesi talon vakiintuneesta tavasta hahmottaa teatterin tehtävä:

"- - talon ulkopuolella meidän tekeminen otetaan hyvin vastaan ja meidän palveluja toivotaan ihan hirveen paljon, ja sillä on kysyntää. Mutta sitte talon sisällä välttämättä ei niistä tiedetä niin paljon. Joku on valittanut, et nyt viedään työpaikka. Tämä johtuu siitä, että ei tiedetä, miksi me soveltavan draaman ammattilaiset ollaan täällä. Kiitosta tulee oppilailta ja opettajilta. Ne, jotka on kiertueella mukana, ymmärtää jo, että sillä on merkitystä, että tehdään muutakin kuin perinteistä draamaa. Toivon, että pikkuhiljaa meidän työ puhuisi puolestaan, että tällä on merkitystä ja tätä tarvitaan.”

Samanaikaisesti joissakin teatteriproduktioissa esitystä valmisteltiin vakiintuneista työtavoista poiketen. Esitys ei välttämättä pohjautunut näytelmäkirjailijan tekstiin, vaan esityksen sisältö syntyi ryhmätyön tuloksena. Pitkän linjan ammattinäyttelijä pohti asiaa näin:

"Kyl se aluksi tuntuu vähän hankalalta - sanotaan joku on tehny teatteria vaikka tossa 25 vuotta, ja se on oppinut tietyn kielen tehdä sitä [teatteria], ja sit jos tulis uusi kieli, niin ei se ookaan ihan sama. Se voi olla vähän outoa, saako näin tehdä, pärjääks mä nyt sitten vain tässä, kun eihän tässä oo mitään varmaa. --Jäi semmonen klangi päähä, että kyl- lä mie oon [tekstiä] kaivannut. Jos näitä tekis pitkään, niin kyl mie myönnän, että kyl mie draamaa [draamatekstiä] kaipaan. Oon miettiny just, että millonhan sitä saa seuraavan kerran tehhä niinku draamatekstiä, mis ois semmonen rooli, mistä pitää. Jos se mahdollisesti ois - Sanon tämän nyt vitsinä, mutta ovi, mistä voi tulla sisään. - Ovella mie tarkotan, miten se rakennetaan se [esitys], että on se on sille draamalle alisteinen se näyttämö, vaikka se ois pelkästään semmonen kuva, mitä katotaan yheltä puolelta."

Esittämäni asetelma on tyypillinen monille organisaatioille: johto ja eri henkilöstöryhmät tarkastelevat organisaation funktiota ja strategiaa eri tavoin. Siksi toiminnan kehittämisessä tulisi ottaa huomioon ihmisten motiivit ja tunteet. Uutta tietoa syntyy, kun ihmiset tuovat tietonsa, motiivinsa ja tunteensa osaksi yhteistä ongelmanratkaisua. Kehittämisen tarinat havainnollistavat erilaisia näkökulmia. Työn oppimisessa ja kehittämisessä ideoita ja asioita voidaan tuoda esiin esimerkiksi roolihenkilöiden avulla.

Teatterissa ja draamassa käsiteltävälle aiheelle annetaan muoto joko fyysisesti, visuaalisesti tai kinesteettisesti. Teatterin ja draaman avulla voidaan käsitellä vastalauseita, kritiikkiä, onnistumisia, epäonnistumisia, turhautumista, tavoitteita, työn rutinoitumista tai muutokseen liittyviä tunteita ja ahdistusta. Teatteri tarjoaa keinot eri näkökulmien, osaamisten ja merkitysten jakamiseen. Teatteria ja draamaa voidaan pitää työn oppimismuotoina, joihin osallistujat ottavat osaa kokonaisvaltaisesti käyttäen kehoaan, mieltään, tunteitaan ja motiiveitaan. Parhaassa tapauksessa nämä tietämisen tasot saadaan käsiteltyä yhdessä, kun ne tuodaan näkyvästi esiin. Teatteri ja draama voidaan nähdä tulevaisuudessa yhtenä työelämän työtapojen muutoksia toteuttavana oppimismuotona ja työelämän kehittymisen menestystekijänä.

Työelämän kehittämisestä draaman ja teatterin keinoin on saatu niin kansainvälisesti kuin kansallisestikin hyviä tuloksia, ja lisäksi on osoitettu taiteen arvo liiketoiminnan kehittämisessä. Vaikka taiteen erilaisia sovellusmahdollisuuksia ymmärretäänkin hyvin, väitän, että tarvitsemme kehittämisprosesseihin kehittämistarpeen systematisoinnin välineitä toisin sanoen metodeja, joilla kehittämisen kohde 
käsitteellistetään. Tämä koskee erityisesti tilanteita, joissa kehittäminen tähtää toimintamallin ja työtapojen muutoksiin. Muutoin haasteena on, että teatteriin perustuvat interventiot jävät viihteellisiksi tai kertaluonteisiksi toteutuksiksi ja kytkös työhön jää puuttumaan. On tärkeää, että interventioissa tekemisen tavoitteet limittyvät yhteen työorganisaatioiden kehittymistavoitteiden kanssa pidemmällä aikavälillä.

Olen tutkinut väitöskirjassani teatteria ja draamaa työn oppimismuotoina organisaation kontekstissa. Tarkastelen teatteria yhtäältä intervention kohteena ja toisaalta teatteria intervention välineenä. Väitöskirjani koostuu viidestä artikkelista ja yhteenvedosta. Yhteenvedossa vastaan seuraaviin tutkimuskysymyksiin: 1) Miten teatteria ja draamaa voidaan jäsentää työn oppimismuotoina? 2) Miten toiminnan teorialla ja kehittävän työntutkimuksen metodologialla voidaan rikastaa teatterin ja draaman tarkastelua?

Tutkimuksen kehittämiskohteina toimivat ammattikorkeakoulun yhden tulosyksikön johtoryhmä ja Rovaniemen Teatteri - Lapin alueteatteri. Toteutin Rovaniemen teatterissa vuosina 2008-2009 yhden vuoden ja kolmen kuukauden mittaisen kehittämishankkeen, jonka aikana koko talon henkilökunta otettiin mukaan kehittämään ja monipuolistamaan esityksen tekotapoja. Kehittämistavoite tuli silloiselta teatterinjohtajalta.

Väitöskirjan toisessa interventiossa kehitettiin ammattikorkeakoulun muutosjohtajuutta vuosina 2012-2013, kun ammattikorkeakouluja oltiin yhtiöittämässä. Tällöin myös esimiesten rooli muutoksen johtamisessa nousi yhä keskeisempään asemaan. Ammattikorkeakoulun muutosjohtajuuden kehittämisessä yhdistin teatterimaailmasta Augusto Boalin kehittämää forum-teatteria ja tutkimusavusteisesta kehittämismaailmasta tulevaa kehittävää työn tutkimusta.

Forum-teatterissa käsiteltävä aihe tehdään näkyväksi draamallisten kohtausten avulla. Forum-teatterin ydinkohtausta kutsutaan antimalliksi. Siinä yleisölle näytetään esitys tai kohtaus, jossa päähenkilö on tekemässä jotakin ja toinen henkilö vastustaa tätä pyrkimystä. Esityksen katsomisen jälkeen katsoja-osallistujien kanssa keskustellaan nähdystä ja yleisölle tarjotaan mahdollisuus muuttaa päähenkilön toimintaa, ja näin antimallille syntyy malli. Forum-teatterin tavoitteena on selvittää, miten päähenkilö voisi toimia toisin ja päästä tavoitteeseensa. Esityksen muuttaminen havainnollistaa konkreettisesti, miten erilaisia ratkaisustrategioita ihmisillä on ja miten eri tavoin tilanteita tulkitaan.

Toin forum-teatterin rinnalle tutkimusavusteisen kehittämismetodin, tarkemmin sanottuna kehittävän työntutkimuksen metodologiasta johtamani kehitysristiriidan. Kehitysristiriitoja ilmenee työtoimintojen muutoksessa, kun esimerkiksi työvälineet, työnjako ja työn pelisäännöt muuttuvat. Kehitysristiriidat havaitaan arjen työssä häiriöinä, katkoksina ja ongelmina. Henkilökohtaisella tasolla kehitysristiriidat koetaan konflikteina, dilemmoina ja työhön liittyvinä uudenlaisina merkityksenantoina. Olen yhdistänyt tutkimuksen avulla luotua analyyttista tietoa ryhmäkeskeiseen harjoitusprosessiin ja tämän prosessin tuloksena syntyneeseen tarinaan.

Interventiossa käsikirjoitimme ja harjoittelimme kahden ammattinäyttelijän kanssa kolmen kohtauksen sarjasta muodostuvan esityksen. Esityksen tarina on muodostettu aineistonkeruun, aineiston analyysin ja teatteriharjoitusprosessin vuoropuhelussa. Intervention tarkoituksena oli luoda tarina, joka peilaisi työtä ja työn haasteita. Tavoitteenani oli, että esityksen avulla käytäisiin keskustelua nykyisistä työtavoista ja siitä, miten jatkossa voitaisiin ja pitäisi toimia toisin.

Tutkimustani on johdattanut hypoteesi, jonka mukaan työntekijöiden kokemuksia työssä koetuista ongelmista ja uudenlaisesta orientoitumisesta työhön voidaan analysoida ja kuvata tarinan avulla. Toiminnan kehittämisen haasteena on usein ihmisiin vaikuttaminen ja työtapojen havainnollistaminen sekä keskustelu niistä. Teatterin ja draaman oppimismuotojen tuominen työelämän valmennuksiin ja interventioihin voi luoda yhteyden abstraktin toiminnan kehittämisen ja käytännön työn välille. Asiat ja ideat voidaan esittää luokitteluina, roolihenkilönä, tilanteena tai kannanottona tarinassa. Tarinaa voidaan hyödyntää vaihtoehtoisena tapana esittää asioita. Nykyisiä työtapoja ja tekemisen tapoja voidaan havainnollistaa ja uusia työtapoja voidaan testata teatterin keinoin. Roolihenkilöiden avulla voidaan testata turvallisesti erilaisia tapoja toi- 
mia. Asiasisältöjä ei tällöin tarkastella "ulkoa käsin" tutkija-kehittäjän johdolla, vaan "sisältä käsin”, jolloin ne yhdistetään reflektion ja tunnekäsittelyn kautta omiin kokemuksiin. Teatteriin perustuvien interventioiden pyrkimyksenä on luoda esteettinen tila, jossa tapahtuu seuraavaa:

"- - roolihenkilön emootiot tunkeutuvat meihin. Esittämämme moraalinen maailma ottaa meistä vallan. Meitä ohjaavat henkilöhahmot ja teot, joita emme enää kontrolloi; me koemme sijaisemootioita. Emme tunne muiden tunteita, vaan projisoimme omiamme esitykseen. Ohjaamme silloin omia tekojamme, olemme subjekteja."

Tällaisessa ilmiössä Boalin mukaan kuulutaan samanaikaisesti ja kokonaisvaltaisesti kahteen maailmaan, todellisuuden kuvaan ja kuvaan todellisuudesta.

Kun esityksessä esitetään eri henkilöhahmojen "todellisuuksia", niistä on helpompi keskustella. Roolihenkilöiden tilannetta muokataan keskustelujen tuloksena. Draama tarjoaa täten konkreettisen paikan testata ja simuloida, tilan "jossitella": mitä tapahtuisi, jos henkilö toimisikin toisin? Näin interventiosta tulee kokemuksellinen ja se mahdollistaa harjoittelun oikeaa elämää varten.

Forum-teatterin tarinaa rakennettaessa tyypillinen asetelma olisi tarkastella ympäristöä sortajasorrettu-linssien läpi. Tällöin olisimme voineet tarkastella ympäröivää muutosta "uhrin" näkökulmasta: "paha työnantaja odottaa minun muuttuvan". Kehitysristiriidan tulkinta tuo sen sijaan enemmän muutoksen mahdollisuuksia. Muutoksen kohteena ei ole ainoastaan "minä suhteessa muihin", vaan sen lisäksi myös käsitys "meidän yhteisestä toimintamallistamme ja yhteisistä työtavoistamme". Miten toimimme nyt? Miten voisimme toimia jatkossa?

Teatteria ja draamaa voidaan suunnitella ja ohjata työntekijöitä osallistaviksi interventioiksi. Teatterin ja draaman interventioissa voidaan käyttää tutkimusavusteisen työnkehittämisen metodeja. Työn kehittämisen metodien sitoumukset vaikuttavat kuitenkin siihen, minkä tason muutosta ja oppimista interventioilla tavoitellaan.

Työn kehittämisen teorioita ja metodeja ei ole vielä yleisesti tunnistettu apukeinoksi suunnitelta- essa teatteriin ja draamaan perustuvia interventioita. Tällainen käyttötapa edellyttäisi tutkimuksellisempaa lähestymistapaa interventioihin. Jos työn kehittämisen teorioita ja metodeja käytetään teatterin ja draaman pedagogian suunnittelussa, voitaisiin interventioissa päätyä ratkaisemaan esimerkiksi toimintamallin, asiakaspalvelukonseptin, johtamisen tai työhyvinvoinnin ongelmia laajemminkin. Teatterilla ja draamalla voitaisiin tällöin muuttaa työyhteisön muodostamia yhteisiä sopimuksia arjen käytänteistä. Tarkoituksena ei olisi ainoastaan saada aikaiseksi yksilötason oivalluksia vaan myös kehittää työryhmien yhteisiä jaettuja ja vakiintuneita ajatteluja toimintatapoja.

Väitöstutkimuksen tuloksena on syntynyt uudenlainen tapa osallistaa henkilökuntaa pohtimaan ja kehittämään organisaationsa toimintaperiaatetta ja omaa työtä. Uutta teatteriin ja tutkimusavusteiseen kehittämiseen perustuvaa menetelmää kutsutaan työyhteisöteatteriksi. Työn tutkimuksellinen kehittämistapa tarjosi työlle paitsi organisaation kehittämisen teorian myös käytännön työkaluja rakentaa tarinaa toimintamallin, työtapojen ja vuorovaikutuksen peiliksi.

\section{Satu-Mari Jansson \\ KM (aikuiskasvatustiede) työyhteisövalmentaja, TheatreWorks tutkijatohtori, ArtsEqual-hanke}

Satu-Mari Janssonin väitöskirja Teatteri ja draama työn oppimismuotoina tarkastettiin Helsingin yliopistossa 13. marraskuuta 2015. 